\title{
GAMBARAN PENGETAHUAN IBU HAMIL TENTANG ASUPAN NUTRISI DI DESA PAWINDAN KECAMATAN CIAMIS KABUPATEN CIAMIS
}

\author{
Ana SamiatulMilah ${ }^{1}$ \\ ${ }^{1}$ Fakultas IImu Kesehatan UNIGAL \\ Email :nengnae@yahoo.com
}

\begin{abstract}
ABSTRAK
Pengetahuan nutrisi merupakan pengetahuan tentang hubungan konsumsi makanan dengan kesehatan tubuh. Ibu hamil dengan pengetahuan nutrisi baik diharapkan dapat memilih asupan makanan yang nilai gizinya dapat memenuhi tubuhnya yang bernilai nutrisi baik dan seimbang bagi dirinya sendiri beserta janin dan keluarga. Tujuan penelitian ini adalah untuk mengetahui sejauh mana gambaran pengetahuan ibu hamil tentang asupan nutrisi di Desa Pawindan Kecamatan Ciamis Kabupaten Ciamis. Jenis penelitian ini adalah penelitian yang bersifat deskriptif. Pada penelitian ini populasinya adalah ibu hamil di Desa Pawindan sebanyak 40 orang dengan teknik sampling secara sengaja dan disproporsional (purposive and unproportional sampling). Jadi sampel yang akan di teliti sebanyak 40 orang. Nutrisi di Desa Pawindan Kecamatan Ciamis Kabupaten Ciamis, diketahui bahwa sebagian besar dari responden $47,5 \%$ atau sebanyak 19 orang dengan tingkat pengetahuan baik. Pengetahuan tentang asupan nutrisi merupakan salah satu faktor yang dapat mempengaruhi konsumsi pangan. Diharapkan masyarakat khususnya ibu-ibu agar lebih mengerti dan memperhatikan kecukupan nutrisi agar selalu dalam kondisi status nutrisi baik dan terjaga kualitas kesehatan.
\end{abstract}

Kata Kunci : Asupan Nutrisi, Pengetahuan, Ibu Hamil.

\begin{abstract}
Knowledge of nutrition is about the relationship between food consumption and body health Pregnant women with good nutrition knowledge are expected to be able to choose food intake whose nutritional value can fill their body with good nutritional value and balance for themselves and their fetus and family. The purpose of this study was to determine the extent of the knowledge of pregnant women about nutrition in Pawindan Village, Ciamis District, Ciamis Regency. This type of research is descriptive research. In this study the population was 40 pregnant women in Pawindan Village with purposive and unproportional sampling techniques. So 40 people will examine the sample. Nutrition in Pawindan Village, Ciamis District, Ciamis Regency, it is known that most of the respondents $47.5 \%$ or as many as 19 people with a good level of knowledge. Knowledge of nutrient intake is one of the factors that can affect food consumption. It is hoped that the community, especially mothers, will better understand and pay attention to the adequacy of nutrition so that they are always in good nutritional status and maintained quality of health.
\end{abstract}

Keywords: Nutrition, Knowledge, Pregnant Women. 


\section{PENDAHULUAN}

Status gizi merupakan ukuran keberhasilan untuk pemenuhan nutrisi untuk ibu hamil. Gizi ibu hamil merupakan nutrisi yang diperlukan dalam jumlah yang sangat banyak untuk pemenuhan gizi ibu sendiri dan perkembangan janin yang dikandungnya. Kebutuhan makanan dilihat bukan hanya dalam porsi yang dimakan tetapi harus ditentukan pada mutu zat-zat gizi yang terkandung dalam makanan yang dikonsumsi (Pengemanan dkk, 2013).

Status gizi ibu hamil merupakan salah satu indicator dalam mengukur status gizi masyarakat. Jika asupan gizi untuk ibu hamil dari makanan tidak seimbang dengan kebutuhan tubuh maka akan terjadi defisiensi zat gizi. Kehamilan menyebabkan meningkatnya metabolism energi. Karena itu, kebutuhan energi dan zat gizi lainnya meningkat selama kehamilan. Peningkatan energi dan zat gizi tersebut diperlukan untuk pertumbuhan dan perkembangan janin, pertambahan besarnya organ kandungan, serta perubahan komposisi dan metabolism tubuh ibu. Sehingga kekurangan zat gizi tertentu yang diperlukan saat hamil dapat menyebabkan janin tumbuh tidak sempurna (Rahmaniar A, 2013).

Angka kematian ibu (AKI) 90\% terjadi di Negara berkembang, pada tahun 2013 adalah 230 per 100.000 kelahiran hidup dibanding 16 per 100.000 kelahiran hidup di Negara-Negara maju. Ibu meninggal akibat komplikasi selama kehamilan. Lebih dari 60.000 kematian ibu di 115 Negara menunjukkan ibu hamil sesudah memiliki riwayat kesehatan yang buruk (seperti diabetes, malaria, HIV (Human Immunodeficiency Virus), obesitas) menyebabkan (28\%) dari kematian. Penyebab lain meliputi pendarahan parah $(27 \%)$, tekanan darah tinggi (14\%), infeksi (11\%), melahirkan dan penyebab langsung lainnya (9\%), komplikasi aborsi $(8 \%)$ dan bekuan darah emboli (3\%) ada hubungannya dengan asupan gizi (World Health Organization, 2014).

Laporan Survei Demografi dan Kesehatan Indonesia (SDKI) tahun 2012 AKI sebesar 359 per 1000 kelahiran hidup (Kemenkes RI, 2014). Lima penyebab kematian ibu terbesar adalah pendarahan $(32 \%)$, hipertensi dalam kehamilan $(25 \%)$, infeksi $(5 \%)$, partus lama $(5 \%)$, dan abortus (1\%). Pendarahan, hipertensi dalam kehamilan, dan infeksi adalah tiga penyebab utama kematian ibu di Indonesia berdasarkan laporan Depkes 2016. Penyebab kematian tersebut erat hubungannya dengan asupan gizi, misalnya pendarahan merupakan salah satu akibat dari kekurangan zat besi, ekslampsia disebabkan oleh hipertensi yang juga ada hubungannya dengan asupan gizi (Almatsier, 2009).

Masa kehamilan merupakan masa dimana ibu membutuhkan berbagai unsur gizi (Karbohidrat, protein, vitamin, mineral, lemak) yang lebih banyak daripada yang diperlukan dari keadaan tidak hamil. Gizi tersebut selain diperlukan untuk memenuhi kebutuhan sendiri diperlukan juga untuk pertumbuhan dan perkembangan janin yang ada didalam kandungan (Moehji, 2013).

Asupan kebutuhan ibu hamil yang tidak tercukupi, dapat berakibat buruk bagi ibu dan janin. Janin dapat mengalami kecatatan lahir dengan berat badan lahir rendah (BBLR), anemia pada bayi, keguguran dan kematian neonatal. Ibu hamil yang kekurangan gizi akan menderita Kurang Energi Kronis (KEK), sehingga berdampak kelemahan fisik, anemia, pendarahan, berat badan ibu tidak bertambah secara normal dan diabetes dalam kehamilan yang membahayakan jiwa ibu. Ibu hamil dengan status gizi kurang akan beresiko melahirkan bayi berat badan lahir rendah 2-3 kali lebih besar dibandingkan yang berstatus gizi baik, disamping kemungkinan bayi meninggal sebesar 1,5 kali (Marlenywati, 2010). 
Laporan status gizi Riset Kesehatan Dasar (Riskesdas) tahun 2012 melaporkan status risiko Kurang Energi Kronik (KEK) ibu hamil berumur 15-49 tahun berdasarkan indicator Lingkar Lengan Atas (LILA) secara nasional sebanyak 24,2\% disebabkan karena kekurangan nutrisi. Pada tahun 2013 Ibuhamil KEK berumur 45-49 tahun naik menjadi $15,1 \%$. Ibu hamil beresiko tinggi yaitu hamil dengan risiko terbesar 31,3\% akibat kekurangan nutrisi. Di Wilayah Jawa Barat 35\%, angka tersebut diatas angka nasional.

Berdasarkan survey Dinas Kesehatan Ciamis pada tahun 2018 jumlah AKI sebanyak 13 orang, AKB 126 orang, kematian balita 14 orang, kematian neonatal (0-28 hari) 68 orang, kematian bayi (1-11 bulan) 28 orang dan jumlah ibu hamil yang mengalami Kekurangan Energi Kronik (KEK) 163 orang, jumlah abortus 110 orang, anemia pada ibu hamil 193 orang, bayi dengan Berat Badan Lahir Rendah (BBLR) sebanyak 46 orang, bayi afiksia 23 orang sangat berhubungan dengan asupan nutrisi (Dinkes Ciamis, 2018).

Dari data yang diperoleh dari Desa Pawindan Wilayah kerja Puskesmas Ciamis Kecamatan Ciamis Kabupaten Ciamis jumlah ibu hamil pada periode bulan Maret-April 2018 sebanyak 40 orang. Ibu hamil yang mengalami Kekurangan Energi Kronik (KEK) sebanyak 5 orang, dan ibu hamil yang mengalami anemia sebanyak 2 orang, berkaitan erat dengan asupan nutrisi (Dinkes Ciamis, 2018).

\section{Status Gizi}

\section{1) Pengertian Gizi}

Pengertian gizi dalam kesehatan reproduksi adalah bagaimana seorang individu, mampu untuk mencukupi kebutuhan gizi yang diperlukan oleh tubuhnya, agar individu tersebut tetap berada dalam keadaan sehat dan baik secara fisik atau mental. Serta mampu menjalankan system reproduksi, baik fungsi atau prosesnya secara alamiah dengan keadaan tubuh yang sehat.

Zat-zat gizi yang dapat memberikan energi adalah karbohidrat, lemak, dan protein, oksidasi zat-zat gizi ini menghasilkan energi yang diperlukan tubuh untuk melakukan kegiatan atau aktivitas. Ketiga zat gizi termasuk zat organik yang mengandung karbon yang dapat dibakar, jumlah zat gizi yang paling banyak terdapat dalam pangan dan disebut juga zat pembakar.

Fungsi utama karbohidrat adalah menyediakan energi tubuh. Karbohidrat merupakan sumber utama energi bagi penduduk di seluruh dunia, sumber karbohidrat adalah padipadian atau sereal, umbi-umbian, kacang-kacangan dan gula (Almatsier, 2010).

Secara umum fungsi zat makanan adalah sebagai berikut

a. Memberi bahan untuk membangun tubuh dan memelihara serta memperbaiki bagian-bagian tubuh yang hilang dan rusak.

b. Memberi kekuatan atau tenaga, sehingga kita dapat bergerak dan bekerja

c. Memberi bahan untuk mengatur proses-proses dalam tubuh

d. Membangun dan memelihara tubuh

Sehubungan dengan hal tersebut diatas, maka untuk mendapatkan kualitas gizi yang baik makanan yang kita konsumsi setiap hari harus mengandung zat-zat gizi, misalnya di Indonesia telah lama dianjurkan mengkonsumsi makanan gizi seimbang yaitu nasi, sayur, lemak, buah, dan susu, sehingga diharapkan dengan mengkonsumsi makanan yang mengandung zat-zat gizi akan 
membantu dalam pertumbuhan dan perkembangan fisik serta energi yang cukup guna melaksanakan kegiatan seharihari.

Berdasarkan uraian di atas, maka gizi merupakan suatu zat yang terdapat dalam makanan yang mengandung karbohidrat, lemak, protein, vitamin dan mineral yang penting bagi manusia untuk pertumbuhan dan perkembangan manusia, memelihara proses tubuh dan sebagai penyedia energi untuk melakukan aktivitas sehari-hari.

Zat Gizi adalah ikatan kimia yang diperlukan tubuh untuk melakukan fungsinya yaitu menghasilkan energi, membangun, memelihara jaringan serta mengatur prosesproses jaringan. Gizi merupakan bagian penting yang dibutuhkan oleh tubuh guna perkembangan dan pertumbuhan dalam bentuk dan untuk memperoleh energi, agar manusia dapat melaksanakan kegiatan fisiknya sehari-hari.

Dari keterangan diatas dapat disimpulkan bahwa gizi adalah bahan makanan yang dikonsumsi oleh tubuh untuk menghasilkan tenaga, membangun dan memelihara jaringan dalam tubuh (Almatsier, 2010).

2) Pengertian Status Gizi

Status gizi adalah keadaan yang diakibatkan oleh status keseimbangan antara jumlah asupan (intake) zat gizi dan jumlah yang dibutuhkan (requirement) oleh tubuh untuk berbagai fungsi biologis (pertumbuhan fisik, perkembangan, aktivitas, pemeliharaan kesehatan dan lainya). Status gizi dapat pula diartikan sebagai gambaran kondisi fisik seseorang sebagai refleksi dari keseimbangan energi yang masuk dan yang dikeluarkan oleh tubuh (Marni, 2013).

\section{3) Pengertian Kehamilan}

Masa kehamilan adalah suatu masa yang dimulai dari konsepsi sampai lahirnya janin, lamanya hamil normal adalah 280 hari $(9$ bulan 7 hari, atau 40 minggu) dihitung dari hari pertama haid terakhir. Masa kehamilan dibagi dalam 3 trimester yaitu:

1) Trimester pertama berlangsung dalam 12 minggu (penambahan berat badan sekitar 1,2 kg).

2) Pada trimester kedua berlangsung dalam 15 minggu (minggu ke-13 hingga ke-27) penambahan berat badan kira-kira 0,35-0,4 $\mathrm{kg}$ per minggu.

3) Trimester ketiga berlangsung dalam 13 minggu (minggu ke-28 hingga ke-40) kenaikan berat badan sekitar $5,5 \mathrm{~kg}$, penambahan BB dari mulai awal kehamilan sampai akhir adalah 11-12 kg. kemungkinan penambahan BB hingga maksimal $12,5 \mathrm{~kg}$ adalah $12,5 \mathrm{~kg}$. (Winjosatro, 2008).

4) Tanda - Tanda Kehamilan

1. Tanda Tidak Pasti

Tanda yang tidak pasti adalah perubahanperubahan fisiologis yang dapat dikenali dan pengakuan atau yang dirasakan oleh wanita hamil. Tanda tidak pasti ini terdiri atas hal - hal berikut ini.

a. Amenore

Konsepsi dan nidasi menyebabkan tidak terjadi pembentukan folikel de graaf dan ovulasi, sehingga menstruasi tidak terjadi. Lamanya amenorea dapat dikonfirmasi 
dengan memastikan hari pertama haid terakhir (HPHT), dan digunakan untuk memperkirakan usia kehamilan dan taksiran persalinan. Tetapi, amenore juga dapat disebabkan oleh penyakit kronik tertentu, tumor pituitari, perubahan dan factor lingkungan, malnutrisi, dan biasanya gangguan emosional seperti ketakutan akan kehamilan.

b. Mual muntah

Pengaruh estrogen terjadi pengeluaran asam lambung yang berlebihan dan menimbulkan mual muntah yang terjadi terutama pada pagi hari yang disebut morning sicknes. Dalam batas tertentu hal ini masih fisiologis, tetapi bila terlampau sering dapat menyebabkan gangguan kesehatan yang disebut dengan hiperemisis gravidarum.

c. Ngidam

Wanita hamil sering menginginkan makanan tertentu, keinginan yang demikian disebut ngidam. Ngidam sering terjadi pada bulan-bulan pertama kehamilan dan akan menghilang dengan makin tuanya kehamilan.

d. Synope (pingsan)

Terjadinya gangguan sirkulasi ke daerah kepala (sentral) menyebabkan iskemia susunan saraf pusat dan menimbulkan synope atau pingsan. $\mathrm{Hal}$ ini sering terjadi terutama jika berada pada tempat yang ramai, biasanya akan hilang setelah 16 minggu.

e. Kelelahan.

Sering terjadi pada trimester pertama, akibat dari penurunan kecepatan basal metabolisme pada kehamilan, yang akan meningkat seiring pertambahan usia kehamilan akibat aktivitas metabolism hasil konsepsi.

f. Payudara tegang

Estrogen meningkatkan perkembangan system duktus pada payudara, sedangkan progesterone menstimulasi

perkembangan system alveolar payudara, menibulkan perasaan tegang dan nyeri selama dua bulan pertama kehamilan, pelebaran putting susu, serta pengeluaran kolostrum.

g. Sering miksi

Desakan Rahim ke depan menyebabkan kandung kemih cepat terasa penuh dengan sering miksi. Frekuensi miksi yang sering, terjadi pada trimester pertama akibat desakan uterus terhadap kandung kemih. Pada trimester kedua umumnya keluhan ini akan berkurang karena uterus yang membesar keluar dari rongga panggul. Pada akhir trimester, gejala bias timbul karena janin mulai masuk ke rongga panggul dan menekan kembali kandung kemih.

h. Konstipasi atau obstipasi Pengaruh progesterone dapat menghambat peristaltic usus (tonus 
otot menurun) sehingga kesulitan untuk BAB.

i. Pigmentasi kulit Pigmentasi terjadi pada usia kehamilan lebih dari 12 minggu. Terjadi akibat pengaruh hormone kortikosteroid plasenta yang merangsang melanofor dan kulit.

j. Epulusi Hipertropi papilla gingivae /gusi, sering terjadi pada trimester pertama.

k. Varises atau penumpukan pembuluh darah vena

Pengaruh estrogen dan progesterone menyebabkan pelebaran pembuluh darah terutama bagi wanita eksterna. Kaki dan betis, serta payudara. Penampakan pembuluh darah ini dapat hilang setelah persalinan.

2. Tanda kemungkinan

Tanda kemungkinan adalah perubahan - perubahan fisiologis yang dapat diketahui oleh pemeriksa dengan melakukan pemeriksaan fisik kepada wanita hamil.

Tanda kemungkinan ini terdiri atas hal - hal berikut.

a. Pembesaran perut

Terjadi

akibat pembesaran uterus. Hal ini terjadi pada bulan keempat kehamilan.

b. Tanda hegar

Tanda hegar adalah pelunakan dan dapat ditekannya isthmus uteri.

c. Tanda goodel

Adalah pelunakan servik. Pada wanita yang tidak hamil servik seperti ujung hidung, sedangkan pada wanita hamil melunak seperti bibir. d. Tanda Chadwick Perubahan warna menjadi keunguan pada vulva dan mukusa vagina termasuk juga porsio dan serviks.

e. Tanda piscasceks Merupakan pembesaran uterus yang tidak simetris. Terjadi karena ovum berimplantasi pada daerah dekat dengan kornu sehingga daerah tersebut berkembang lebih dulu.

f. Kontraksi braxton hicks Merupakan peregangan sel - sel otot uterus, akibat meningkatnya actomysin di dalam otot uterus. Kontraksi ini tidak beritmik, sproradis, tidak nyeri biasanya timbul pada kehamilan delapan minggu, tetapi baru dapat diamati dari pemeriksaan abdominal pada trimester ketiga, kontraksi ini akan terus meningkat frekuensinya, lamanya, dan kekuatannya sampai mendekati persalinan.

g. Teraba ballatoment Ketukan yang mendadak pada uterus menyebabkan janin bergerak dalam cairan ketuban yang dapat dirasakan oleh tenaga pemeriksa. Hal ini harus ada pada pemeriksaan kehamilan karena perabaan bagian seperti bentuk janin saja tidak cukup karena dapat saja merupakan myoma uteri.

h. Pemeriksaan tes biologis kehamilan positif

Pemeriksaan ini adalah untuk mendeteksi adanya human chorionic gonodotropin (HCG) yang diproduksi oleh 
sinsiotropoblastik sel selama kehamilan. Hormon ini disekresi di peredaran dan ibu (pada plasma darah), dan di ekskresi pada urin ibu. Hormon ini dapat mulai dideteksi pada 26 hari setelah konsepsi dan meningkat dengan cepat pada hari ke $30-60$. Tingkat tertinggi pada hari 60 - 70 usia gestasi, kemudian menurun pada hari ke $100-130$.

3. Tanda Pasti Kehamilan

Tanda pasti adalah tanda yang menunjukan langsung keberadaan janin, yang dapat dilihat oleh pemeriksa. Tanda pasti kehamilan terdiri atas hal - hal berikut :

a. Terdengar

denyut jantung (DJJ)

Dapat didengar pada usia 12 minggu dengan menggunakan alat fetal electrocardiograf

(misalnya dopler). Dengan stetoskop leanec, DJJ (Denyut Jantung Janin) baru dapat didengar pada usia kehamilan sekitar 20 minggu.

b. Gerakan janin

Gerakan janin ini harus dapat diraba dengan jelas oleh pemeriksa. Gerakan janin baru dapat dirasakan pada usia kehamilan sekitar 20 minggu.

c. Bagian - bagian janin Bagian - bagian janin yaitu bagian besar janin (kepala dan bokong) serta bagian kecil janin (trimester terakhir). Bagian janin ini dapat dilihat lebih sempurna lagi menggunakan USG (Ultrasonography). d. Kerangka janin Kerangka janin dapat dilihat dengan foto rontgen maupun USG (Ultrasonography).

(Prawirohardjo, 2011)

5) Kebutuhan Nutrisi Ibu Hami Kebutuhan selama hamil yang berbeda-beda untuk setiap individu dan juga dipengaruhi oleh riwayat kesehatan dan status gizi sebelumnya, kekurangan asupan salah satu zat akan mengakibatkan kebutuhan terhadap suatu nutrient terganggu, dan kebutuhan nutrisi yang tidak konstan selama kehamilan :

a. Energi

Selama proses kehamilan terjadi peningkatan kebutuhan kalori sejalan dengan adanya peningkatan laju metabolik basal dan penambahan berat badan yang akan meningkatan penggunaan kalori selama aktifitas. Pada awal kehamilan trimester I kebutuhan energi masih sedikit dan terjadi sedikit peningkatan pada trimester II dan trimester III kebutuhan energi pada wanita dewasa 2500 kalori, terjadi peningkatan 300 kalori pada wanita hamil.

b. Protein

Penambahan protein selama kehamilan tergantung kecepatan pertumbuhan janinnya. Kebutuhan protein pada trimester I hingga trimester II kurang dari 6 gram setiap harinya, sedangkan pada trimester III sekitar 10 gram tiap harinya. Kebutuhan protein bias didapat dari nabati maupun hewani. Sumber hewani seperti daging tak berlemak, ikan, telur, susu. Sedangkan sumber nabati seperti tahu, 
tempe dan kacang-kacangan protein digunakan untuk pembentukan jaringan baru baik plasenta dan janin, pertumbuhan dan defisiensi sel, pembentukan cadangan darah dan persiapan masa menyusui.

c. Lemak

Lemak merupakan tenaga yang vital dan untuk pertumbuhan jaringan plasenta. Lemak dibutuhkan tubuh terutama untuk membentuk energi dan serta perkembangan system saraf janin. Oleh karena itu, ibu hamil tidak boleh sampai kurang mengkonsumsi lemak tubuh. Kadar lemak akan meningkat pada trimester III.

d. Karbohidrat

Sumber utama untuk tambahan kalori yang di butuhkan selama kehamilan untuk pertumbuhan dan perkembangan janin adalah karbohidrat komplek seperti roti, serelia, nasi dan pasta. Karbohidrat komplek mengandung vitamin dan mineral serta meningkatkan asupan serat untuk mencegah terjadinya konstipasi.

e. Vitamin

Ibu hamil membutuhkan lebih banyak vitamin dibandingkan wanita yang tidak hamil. Kebutuhan vitamin diperlukan untuk mendukung pertumbuhan dan perkembangan janin serta proses diferensiasi sel. Kebutuhan vitamin meliputi:

1) Asam folat

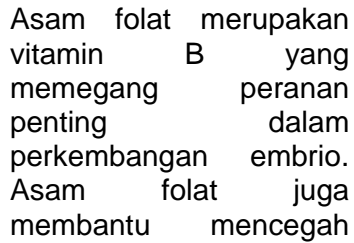

neural tube defect, yaitu cacat pada otak dan tulang belakang. Kekurangan asam folat dapat menyebabkan kehamilan prematur, cacat bawaan, anemia, bayi dengan berat badan lahir rendah (BBLR), dan pertumbuhan janin teganggu. Asam folat dapat didapatkan dari suplemen asam folat, sayuran berwarna hijau, jeruk, buncis, kacangkacangan dan roti gandum.

2) Vitamin A untuk penglihatan, imunitas pertumbuhan dan perkembangan embrio. Kekurangan vitamin $A$ menyebabkan kelahiran prematur dan berat badan lahit rendah. Sumber vitamin A antara lain: buah-buahan, sayuran warna hijau atau kuning, mentega, susu, kuning telur dan lainnya.

3) Vitamin $B$

Vitamin B1, vitamin B2, niasin dan asam pantotenat yang dibutuhkan untuk membantu proses metabolisme. Vitamin B6 dan B12 diperlukan untuk membentuk DNA dan sel-sel darah merah. Vitamin B6 berperan dalam metabolism asam amino.

4) Vitamin $C$

Vitamin C merupakan antioksidan yang melindungi jaringan dari kerusakan dan dibutuhkan untuk membentuk kolagen serta menghantarkan sinyal ke otak. Vitamin C juga membantu 
penyerapan zat besi di dalam tubuh. Ibu hamil disarankan mengonsumsi 85 miligram per hari. Sumber vitamin C didapat dari papaya, jeruk, strawbery, jambu biji dan brokoli.

5) Vitamin $D$

Vitamin D berfungsi mencegah hipokalsemia, membantu penyerapan kalsium dan fosfor. Mineralisasi tulang dan gigi serta mencegah osteomalacia pada ibu. Sumber vitamin D terdapat pada susu, kuning telur dan dibuat sendiri oleh tubuh dengan bantuan sinar matahari.

6) Vitamin E

Vitamin E berfungsi untuk pertumbuhan sel dan jaringan serta integrase sel darah merah. Selama kehamilan wanita hamil dianjurkan mengonsumsi 2 miligram per hari.

7) Vitamin $\mathrm{K}$

Kekurangan vitamin $\mathrm{K}$ dapat mengakibatkan gangguan pendarahan pada bayi, pada umumnya kekurangan vitamin $\mathrm{K}$ jarang terjadi, karena vitamin $\mathrm{K}$ terdapat banyak pada banyak jenis makanan dan dapat juga disintesis oleh bakteri usus.

f. Mineral

Wanita hamil juga membutuhkan lebih banyak mineral dibandingkan sebelum hamil. Kebutuhan mineral diperlukan untuk mendukung pertumbuhan dan perkembangan janin serta proses diferensiasi sel. Kebutuhan mineral antara lain:
1) Zat besi

Zat besi akan meningkat 200-300 miligram dan selama kehamilan yang dibutuhkan sekitar 1040 miligram. Zat besi dibutuhkan untuk memproduksi

hemoglobin. Yaitu protein di sel darah merah yang berperan membawa oksigen ke jaringan tubuh. Defisiensi zat besi akan berakibat ibu hamil mudah lelah dan rentan infeksi. Resiko persalinan prematur dan berat badan bayi lahir rendah. Efek samping dari zat besi adalah konstipasi dan nausea (mual muntah). Zat besi dapat ditemukan pada daging, ikan kerang, unggas, sereal, dan kacangkacangan.

2) Zat seng

Zat seng digunakan untuk pembentukan tulang selubung saraf tulang belakang. Resiko kekurangan seng menyebabkan kelahiran prematur dan berat badan bayi lahir rendah. Kebutuhan seng pada mengandung zat seng antara lain: kerang, daging, kacangkacangan, sereal.

3) Kalsium

Ibu hamil membutuhkan kalsium untuk pembentukan tulang dan gigi, membantu pembuluh darah berkontraksi dan berdilatasi, serta mengantarkan sinyal saraf. Kontraksi otot dan sekresi hormon Kebutuhan kalsium di dapat dari teri, susu, 
udang, sarden, sayuran hijau dan youghurt.

4) Yodium

Ibu hamil dianjurkan mengonsumsi yodium sekitar 200 miligram dalam bentuk garam beryodium. Kekurangan yodium dapat menyebabkan hipotirodisme yang berkelanjutan menjadi kretinisme.

5) Fosfor

Fosfor berperan dalam pembentukan tulang dan gigi janin serta kenaikan metabolism kalsium ibu. Kekurangan fosfor akan menyebabkan kram pada tungkai.

6) Flour

Flour diperlukan tubuh untuk pertumbuhan tulang dan gigi. Kekurangan flour terdapat dalam air minum.

7) Natrium

Natrium berperan dalam metabolisme air dan bersifat mengikat cairan dalam jaringan sehingga memengaruhi

keseimbangan cairan tubuh pada ibu hamil. Kebutuhan natrium meningkat seiring dengan meningkatnya kerja ginjal. Kebutuhan natrium ibu hamil sekitar 3,3 gram per minggu.

6) Pola Makan dan Status Gizi Ibu Hamil

Status gizi ibu hamil mempunyai dampak langsung pada perjalanan kehamilan dan bayi yang akan dilahirkanya. Malnutrisi yang terjadi pada bulan awal kehamilan memengaruhi perkembangan dan kapasitas embrio untuk bertahan hidup, nutrisi yang buruk pada masa lanjut kehamilan memengaruhi pertumbuhan janin (Almatsier, 2009).

Makanan ibu hamil mempunyai peranan penting bagi tumbuh kembang janin dan pada saat ibu melahirkan. Selama kehamilan seorang ibu akan mengalami perubahan baik anatomis, fisiologis, maupun perubahan lainnya yang akan meningkatkan kebutuhan zat gizi dalam makananya. Di dalam Rahim ibu terdapat janin yang sedang tumbuh, di tempat lain beberapa organ tubuh ibu mengalami perubahan fungsi dalam rangka mempersiapkan kehadiran sang bayi.

Banyaknya makanan yang dibutuhkan oleh ibu hamil tergantung dari kondisi badan ibu. Namun jika terjadi gangguan masa kehamilan maka dapat diatur sebagai berikut :

a. Pada Trimester I:

Pada umur kehamilan 1-3 bulan kemungkinan terjadi penurunan berat badan. Hal ini disebabkan adanya gangguan pusing, mual bahkan muntah. Untuk itu dianjurkan porsi makanan kecil tetapi sering. Bentuk makanan kering/ tidak berkuah.

b. Pada Trimester II :

Nafsu makan ibu membaik, makan makanan yang diberikan: $3 x$ sehari di tambah 1x makanan selingan. Hidangan lauk pauk hewani seperti: telur, daging. Teri, hati sangat baik dan bermanfaat untuk menghindari kurang darah.

c. Pada Trimester III :

Makanan harus disesuaikan dengan keadaan badan ibu. Bila ibu hamil mempunyai berat badan kelebihan, maka makanan pokok dan tepungtepungan dikurangi, dan 
memperbanyak sayursayuran dan buah-buahan segar untuk menghindari sembelit.

Untuk kesehatan ibu selama kehamilan maupun pertumbuhan dan aktifitas defisiensi janin maka ibu dalam keadaan hamil cukup mendapat makanan bagi dirinya sendiri maupun bagi janinya. Makanan yang bias dikonsumsi ibu hamil berguna juga dalam rangka memudahkan kelahiranya dan untuk produksi Air Susu lbu (ASI). Bagi bayi yang akan dilahirkan (Suryati, 2011).

\section{7) Faktor-Faktor}

\section{Memengaruhi Status Gizi}

a. Faktor eksternal

Faktor eksternal yang memengaruhi status zat gizi antara lain :

1) Pendapatan

Masalah gizi karena kemiskinan indikatornya adalah taraf ekonomi keluarga, yang hubungannya dengan daya beli keluarga tersebut.

2) Pendidikan

Pendidikan

merupakan suatu proses merubah pengetahuan, sikap dan perilaku orang tua atau masyarakat tentang status gizi yang baik.

3) Pekerjaan

Pekerjaan adalah sesuatu yang harus dilakukan terutama untuk menunjang kehidupan keluarganya. Berkerja bagi ibu-ibu akan mempunyai pengaruh terhadap kehidupan keluarga.

4) Budaya

Budaya adalah suatu ciri khas, akan memengaruhi tingkah laku dan kebiasaan masyarakat.

b. Faktor internal Faktor internal yang
memengaruhi status gizi
antara lain:

1) Usia

Usia akan memengaruhi

kemampuan atau

pengalaman yang dimiliki

orang tua dalam

pemberian nutrisi anak dan remaja.

2) Kondisi fisik

Seseorang yang sakit, yang sedang dalam penyembuhan dan yang lanjut usia, semuanya memerlukan pangan khusus karena status kesehatan mereka yang buruk.

3) Infeksi

Infeksi dan demam dapat menyebabkan

menurunya hawa nafsu makan atau menimbulkan kesulitan menelan dan mencerna makanan (Almatsier, 2010).

8) Tanda - tanda Kecukupan Gizi pada Ibu Hamil

Tabel I Tanda - Tanda Kecukupan gizi Pada Ibu Hamil

\begin{tabular}{ll} 
Status & Tandakecukupangizi yang tepat \\
\hline Berat & Normal (Berat badan sesuaidengantinggi
\end{tabular}

badan badan)

Bibir Warnatidakpucat, lembab, dan tidakbengkak Gusi Merah normal dan tidakadapendarahan Jantung Detak dan iramajantung normal,
tekanandarah normal

Keadaa Gesit dan responsive

numum Tidakkusam, cukuplembab, dan tidakkering Kulit

Kuku Keras, warnanyakemerahan

Kelenjar Tidakadapembesaran

Kaki Tidakbengkak

Leher Warnasamadenganmuka, cukuplembab, tampaksegar, dan sehat

Muka Warnasamadenganleher, cukuplembab,

$\begin{array}{ll} & \text { tampaksegar dan sehat } \\ \text { Mulut } & \text { Tidakadaluka }\end{array}$ 


\begin{tabular}{ll} 
Mata & $\begin{array}{l}\text { Bersih, bersinar, selaputbesarberwarnamrah } \\
\text { dan tidakadapendarahan }\end{array}$ \\
Otot & $\begin{array}{l}\text { Kuat, dan } \\
\text { bawahkulitsedikitlemaknya }\end{array}$ \\
$\begin{array}{l}\text { Posturtu } \\
\text { buh }\end{array}$ & $\begin{array}{l}\text { Tegak, lengan dan tungkailurus } \\
\text { Pencern }\end{array}$ \\
$\begin{array}{l}\text { aan } \\
\text { Rambut }\end{array}$ & $\begin{array}{l}\text { Mengkilap, tidakrontok, dan } \\
\text { kulitkepalabersih }\end{array}$ \\
Saraf & $\begin{array}{l}\text { Reflek normal, mental stabil, dan } \\
\text { tidakmudahtersinggung } \\
\text { Dayatahantubuhbaik, semangat, cukuptidur, } \\
\text { dan enegik }\end{array}$ \\
\hline $\begin{array}{l}\text { Vasilitas } \\
\text { umum }\end{array}$ & \\
\hline
\end{tabular}

9) Dampak Kekurangan Nutrisi Bagi lbu Hamil dan Bayi

Bila ibu mengalami kekurangan gizi selama hamil akan menimbulkan masalah baik pada ibu maupun janin.

a. Terhadap ibu

Gizi kurang pada ibu hamil dapat menyebabkan resiko dan komplikasi pada ibu, antara lain :

1) Pendarahan

2) Berat badan ibu tidak bertambah secara normal dan bias terkena penyakit infeksi, dan pada akhirnya juga dapat menurunkan status gizi.

3) Dapat menyebabkan anemia selama kehamilan

4) Dapat menyebabkan Kekurangan Energi Kronik (KEK)

Yaitu ibu hamil kekurangan gizi (kalori dan protein). Dan apabila pengukuran Lingkar Lengan Atas (LILA) < $23,5 \mathrm{~cm}$.

b. Terhadap persalinan

Pengaruh gizi kurang pada ibu hamil dapat mengakibatkan :

1) Persalinan sulit dan lama

2) Persalinan sebelum waktunya (prematur)

3) Pendarahan setelah persalinan serta persalinan dengan operasi cenderung meningkat. c. Terhadap janin

Kekurangan asupan zat gizi pada ibu hamil dapat memengaruhi proses pertumbuhan janin dan dapat menimbulkan :

1) Keguguran (Abortus)

2) Bayi mati di dalam kandungan

3) Cacat bawaan

4) Anemia pada bayi

5) Afiksia

6) Bayi lahir dengan Berat Badan Bayi Lahir Rendah (BBLR).

(Suryati, 2017)

\section{METODE PENELITIAN}

\section{Jenis Dan Rancangan Penelitian}

Jenis penelitian ini adalah penelitian yang bersifat deskriptif. Penelitian deskriptif adalah suatu metode penelitian yang dilakukan dengan tujuan utama untuk membuat gambaran atau deskriptif tentang suatu metode penelitian yang dilakukan dengan tujuan utama untuk membuat gambaran atau deskriptif tentang suatu keadaan secara objektif dan digunakan untuk memecahkan atau menjawab permasalahan yang sedang dihadapi pada situasi sekarang (Notoatmodjo, 2014).

1. Rancangan Penelitian

Rancangan penelitian yang digunakan adalah rancangan penelitian survei. Penelitian survey yaitu suatu desain yang digunakan untuk menyediakan informasi yang berhubungan dengan, distribusi dan hubungan antar variable dalam suatu populasi (Nursalam, 2010).

\section{Populasi dan Sampel}

1. Populasi

Populasi penelitian adalah keseluruhan objek penelitian atau objek yang diteliti. Pada penelitian ini adalah seluruh ibu hamil trimester 
I dan II periode bulan Maret-April di Wilayah Desa Pawindan Kecamatan Ciamis Kabupaten Ciamis yang berjumlah 40 orang.

\section{Sampel}

Sampel adalah sebagian yang diambil dari keseluruhan objek penelitian diangga pmewakili seluruh populasi. Pada penelitian 40 ibu hamil karena populasinya kurang dari 100 orang maka populasi dijadikan sampel (Notoatmodjo, 2010).

\section{Subjek Penelitian}

Subjek dalam penelitian ini adalah seluruh ibu hamil trimester I dan II di Desa Pawindan wilayah Kerja Puskesmas Pawindan Kecamatan Ciamis Kabupaten Ciamis.

\section{Lokasi Penelitian}

Penelitian mengenai Gambaran Pengetahuan lbu Hamil tentang Asupan Nutrisi akan dilakukan di Desa Pawindan Wilayah Kerja Puskesmas Pawindan Kecamatan Ciamis Kabupaten Ciamis Pada Bulan Mei - Agustus 2018.

\section{Definisi Operasional}

\begin{tabular}{|c|c|c|c|c|c|}
\hline $\begin{array}{l}\mathrm{N} \\
\mathrm{o}\end{array}$ & Variabel & $\begin{array}{c}\text { Definisi } \\
\text { Operasional }\end{array}$ & $\begin{array}{l}\text { Alat } \\
\text { Ukur }\end{array}$ & Katagori & Skala \\
\hline 1 & $\begin{array}{l}\text { Pengetahuan } \\
\text { Ibu Hamil } \\
\text { Tentang } \\
\text { Asupan } \\
\text { Nutrisi }\end{array}$ & $\begin{array}{lr}\text { Adalah kemampuan } \\
\text { ibu untuk menjawab } \\
\text { dengan benar } \\
\text { pertanyaan tentang } \\
\text { pengertian asupan } \\
\text { nutrisi bagi ibu hamil, } \\
\text { dampak kekurangan } \\
\text { nutrisi ibu hamil, } \\
\text { macam-macam } \\
\text { sumber nutrisi. Tanda } \\
\text { kecukupan gizi ibu } \\
\text { hamil }\end{array}$ & $\begin{array}{l}\text { Kuisi } \\
\text { oner }\end{array}$ & $\begin{array}{l}\text { Baik: } \\
76- \\
100 \% \\
\text { Cukup : } \\
56 \\
75 \% \\
\\
\text { Kurang : } \\
56 \%\end{array}$ & Ordinal \\
\hline
\end{tabular}

\section{Instrumen Penelitian}

Instrumen yang digunakan dalam penelitian ini adalah lembar kuisioner untuk responden. Kuisioner adalah jumlah pertanyaan tertulis yang digunakan untuk memperoleh informasi dari responden dalam arti laporan pribadinya atau hal - hal yang diketahui (Arikunto, 2011).

\section{Uji Validitas dan Reliabilitas}

\section{Uji Validitas}

Validitas adalah suatu ukuran yang menunjukkan tingkat-tingkat kevalidan atau kesahihan suatu instrumen. Suatu instrumen yang valid atau shahih mempunyai validitas tinggi, sebaliknya istrumen yang kurang valid berarti memiliki validitas rendah. Uji validitas pada penelitian ini akan dilakukan dengan cara pengujian validitas eksternal, yaitu instrumen yang dicapai apabila data yang dihasilkan dari instrument tersebut sesuai dengan data atau informasi lain yang mengenai variable penelitian yang dimaksud. Rumus yang digunakan yaitu rumus kolerasi yang dikemukakan oleh Person yang dikenal dengan rumus kolerasi product moment sebagai berikut :

$r_{x y}=\frac{\sum x y}{\left(\sum x^{2}\right)\left(\sum y^{2}\right)}$

Keterangan:

$\mathrm{X}: \mathrm{X}-\mathrm{X}$

$y: Y-Y$

$X:$ Skor rata -rata dari $X$

Y: Skor rata - rata dari $Y$ (Arikunto, 2006).

Item valid jika koefisien kolerasi antara skor item dengan skor $r$ hitung dinyatakan valid apabila nilai $r$ tabel $(0,05)$. Semakin tinggi nilai koefisien kolerasi suatu item menunjukkan semakin tingginya validitas item tersebut. Uji validitas dilaksanakan di Desa Margaluyu kepada 20 orang ibu hamil trimester I dan II, berdasarkan hasil uji validitas terhadap 20 pertanyaan, diperoleh nilai $r$ hitung sebesar 0,754-0,996 $>r$ tabel 0,312, artinya semua pertanyaan valid.

\section{Uji Reliabilitas}

pada suatu pengertian bahwa sesuatu instrument cukup dapat 
dipercaya untuk digunakan sebagai alat pengumpul data karena instrument tersebut sudah baik. Uji reliabilitas pada penelitian ini menggunakan rumus Alpha Cronbach, dengan pertimbangan bahwa reliabilitas Alpha Cronbach dapat dipergunakan baik untuk instrumen yang jawabannya berskala maupun yang bersifat dikhotomis. Adapun rumus koefisien reliabilitas Alpha Cronbach adalah sebagai berikut :

$r=\frac{K}{k-1}\left(1-\frac{\sum \sigma i^{2}}{\sigma^{2}}\right)$

Keterangan:

$r$ : Koefisien reliabilitas yang dicar

$\mathrm{k}$ : Jumlah butir pertanyaan (soal)

(soal)

$\sigma i^{2}$ :Varians butir - butir pertanyaan

$\sigma^{2}:$ Varians skor tes

Varians butir itu sendiri dapat diperoleh dengan menggunakan rumus sebagai berikut :

$$
\sigma i=\frac{\sum x 1^{2}-\left(\frac{\sum x i}{N}\right)^{2}}{N}
$$

Keterangan :

$\sigma i^{2} \quad$ : Varians butir pertanyaan ke - $\mathrm{n}$ (misalnya ke-1, ke2, dan seterusnya)

$\sum x_{1}$ : Jumlah skor jawaban subjek untuk butir pertanyaan ke-n.

Instrumen reliable jika koefisien Reliabilitas Alpha Cronbach berharga $\geq 0,70$ (Sugiyono, 2010) Semakin tinggi nilai koefisien reliabilitas suatu instrument tersebut. Setelah Uji Validitas yang dilaksanakan di Desa Pawindan kepada 20 orang ibu hamil didapatkan hasil $r$ hitung $(0,761) \geq r$ table $(0,70)$. Artinya semua pertanyaan reliable dan kuisioner dapat dijadikan alat ukur pada penelitian ini.

\section{Analisa Data}

Analisa data yang digunakan dalam penelitian ini adalah analisis univariat yaitu data yang diperoleh dikumpulkan dan dituangkan kedalam table distribusi frekuensi dengan perhitungan analisa. Rumusan analisis univariat adalah :

$\mathrm{P}: \frac{F}{N} \times 100 \%$

Keterangan :

$\mathrm{P}=$ Jumlah presentasi yang dicari

$F=$ Jumlah jawaban responden yang benar 2011)

$\mathrm{N}$ = Jumlah pertanyaan (Arikunto,

Selanjutnya presentase yang diperoleh dimasukkan ke dalam standar criteria objektif, yang bersifat kuantitatif yaitu :

Tingkat pengetahuan

Baik:76 - 100\%

Cukup:56 \% - $75 \%$

Kurang:<56 \% (Arikunto, 2011).

\section{SIMPULAN DAN SARAN}

Berdasarkan pada hasil Penelitian dan pembahasan dapat diperoleh kesimpulan bahwa, Pengetahuan lbu Hamil tentang Asupan Nutrisi di Desa Pawindan Kecamatan Baregbeg Kabupaten Ciamis, diketahui bahwa sebagian besar dari responden $(47,5 \%)$ atau sebanyak 19 orang dengan tingkat pengetahuan baik. Diharapkan bagi petugas kesehatan dengan adanya Germas (Gerakan Masyarakat) di harapkan dapat memberikan penyuluhan tentang kecukupan nutrisi pada ibu Hamil agar selalu dalam kondisi status nutrisi baik dan terjaga kesehatannya serta kepada pihak Puskesmas dapat digunakan sebagai dasar perimbangan dalam perencanaan program nutrisi di Wilayah Puskesmas Desa Pawindan. Bagi masyarakat dengan adanya Germas (Gerakan Masyarakat) khususnya ibu-ibu agar lebih mengerti dan memperhatikan kecukupan nutrisi untuk memenuhi kebutuhan asupan nutrisi agar selalu dalam kondisi status nutrisi baik dan terjaga kualitas kesehatannya. 


\section{DAFTAR PUSTAKA}

Almatsier, Sunita, 2010. Penuntun Diet Edisi Baru. Jakarta: Gramedia.

Almatsier, Sunita. 2010. Prinsif Dasar IImu Gizi. Jakarta: Gramedia.

Arikunto.2011. Prosedur Penelitian Suatu Pendekatan Praktek. Edisi Revisi V. Rineka Cipta. Jakarta.

Berg A, Kodyat. 2003. Kesehatan dan Gizi Keluarga. Jakarta: Bumi Aksara

Depkes RI, 2007. Kesehatan Bag ibu Hamil. Pusat Promosi Kesehatan Kementrian Kesehatan RI. Jakarta.

Dinkes. Januari 2018. Laporan Rekapan Bulanan. Kabupaten Ciamis

Hermawan. 2013. Penelitian Bisnis Paradigma Kuantitatif. Jakarta : PT. Grasindo

Hidayat. 2016. Keterampilan Dasar Praktik Klinik Untuk Kebidanan. Salemba Medika. Jakarta.

Irianto, Djoko Pekik. (2011), Penilaian Status Gizi. Yogjakarta : FIK UNY.

Marlenywati. 2015. Risiko Kurang Energi Kronik (KEK) pada ibu hamil remaja (Usia 15-19 Tahun) di kota Pontianak 2013. Tesis. Fakultas Kesehatan Masyarakat. UI. Depok.

Marni. 2013. Asuhan Kebidanan Pada Masa Antenatal. Yogjakarta: Pustaka Belajar.

Notoatmodjo. 2010. Metodologi penelitian kesehatan. Jakarta: PT. Rineka Cipta

Notoatmodjo.2011. Pendidikan dan Perilaku Kesehatan. Rineka Cipta. Jakarta.

Notoatmodjo. 2013. Metodologi Penelitian Kesehatan Edisi Revisi. Rineka Cipta Jakarta.
Nursalam. (2010). Konsep dan Penerapan Metodologi Penelitian IImu Keperawatan. Jakarta: Salemba Medika.

Moehji, S. 2014. ILMU GIZI 2. Penerbit Papas Sinar-Sinarti. Jakarta: 63.66 .

WHO.2014. Media Center.Countries vow to combat malnutrition throught firm policies and actions

Wiknjosastro. 2008. IImu Kebidanan. Yayasan Bina Pustaka

Sarwono Prowirohardjo. Jakarta. Hubungan Pengetahuan dan Sikap lbu Hamil dengan Status Gizi Selama Kehamilan. Prodi Keperawatan Fakultas Kedokteran Universitas Ratulangi.

Rahmaniar, A., Taslim., M., Bahar B. 2011. Faktor-faktor yang Berhubungan dengan Kekurangan Energi Kronik Pada Ibu Hamil. Makasar: Media Gizi Pangan. 2015.

Suhardjo, 2003. Berbagai Cara Pendidikan Gizi. Bumi Aksara, Jakarta

Saddulloh, dkk. 2009. Pedagogik. Cipta Utama. Bandung.

Supariasa. 2012. Penilaian Status Gizi. Penerbit Buku Kedokteran EGC. Jakarta.

Suryati. 2011. Buku Ajar ASKEB 1: Konsep Dasar Asuhan Kehamilan. Yogjakarta: Nuha Medika. 
